\title{
Roving Sustainable Coastal Tourism in Wediombo
}

\author{
S. H. Hengky \\ Universitas Bina Darma, Prasetiya Mandiri, Indonesia \\ E-mail: hengky_halim@binadarma.ac.id; hengky_halim@yahoo.com.au
}

Received: July 31, 2018 Accepted: August 17, 2018 Published: September 6, 2018

doi:10.5296/emsd.v7i4.13610 URL: https://doi.org/10.5296/emsd.v7i4.13610

\begin{abstract}
The number of tourists visiting Wediombo is targeted to increase by $15 \%$ proportionally by Head of Yogyakarta Tourism of Indonesia in 2018. This study was conducted for roving the Wediombi of sustainable coastal tourism for almost a year. The concept would increase tourist motivation to visit it to. The problem indicated the performance of the supporting social communication and infrastructure was important to supporting coastal tourism activities. Therefore, the performance of the coastal tourism can still be improved by increasing some of the factors of sustainable coastal tourism proportionally. It would be discussed further in the discussion on. Without realized, this analyzed found other kind of potential coastal tourism. The local community did not know about for several traditional culinary tourisms. It can also help improve its performance, as well as economic growth of coastal communities and improve their welfare.
\end{abstract}

Keywords: Sustainable coastal tourism, Culinary tourism, Social communication

\section{Introduction}

Yogyakarta is not only known as a place of cultural tourism, culinary, and shopping. This special city is increasingly ogled the tourists because of its natural beauty. Head of Yogyakarta Tourism Office said that in 2017, there were 4.7 million domestic tourists visiting Yogyakarta. The amount, already exceeding the target of 4.5 million domestic tourists, which has proclaimed before. As for all tourist, the number reached 397,000 people that visited Yogyakarta during 2017. Wediombo beach is located in Yogyakarta. While, the local government are trying to increase the number of tourists visiting this beach (Ara, 2018).

In 2018, tourist arrivals in Yogyakarta were targeted to increase by 10-15\%. This increase will occur, as well as the infrastructure that supports the visit to tourists is getting better. Railway and bus transportations are also very accessible to their activities. Then homestay-homestay in the tourist village a lot and good and has been visited by tourists. This is our optimism in 2018. Based on research conducted in 2015, money circulating in this area 
from foreign tourists visited to USD 214 million. The study will be done again in the very near future of the other topics about their behaviour. This study was conducted to respond to the target of Head of Yogyakarta Tourism and roving sustainable coastal tourism in Wediombo.

\section{Literature Review}

The mobility of tourists, capital, labour, expertise, resources and images creates significant challenges for sustainable governance of destinations. The mobility of the destination creates the physical, social, economic and political characteristics of a place that is affected by the population of tourists, residents, second homeowners and recreation, and the flow of transnational labour and venture capital. Three keys processed affecting destination management: spatial restructuring, pluralization of destination management and re-envisioning communities (Dredge \& Jamal, 2013).

Over the years, the sustainability of the tourism industry has been widely recognized. Unfortunately, however, it is hindered in collaborative efforts of stakeholders. Collaboration, particularly done through multi-stakeholder partnerships. It has been seen as an effective way to support initiatives in tourism development. Successful collaboration and partnership in tourism development on the island of Gili Trawangan, Indonesia through a multi-method approach consisting of environmental audits and semi-structured interviews. The developed partnership, called Gili Ecotrust has been proven to provide a successful example of collaboration and lead to the implementation of innovative sustainability initiatives on the island (Graci, 2013).

Sihanoukville is a city beach that composes programs and combines practices to make destinations more sustainable. The coastal destination as the global community. It called for sustainable practices. The destination is one of the newly emerging coastal resorts to Asia. The coastal management learns from other less sustainable Asian destinations. The Cambodian Government is partnering with international agencies in an effort to better understand the effectiveness and success in implementing the sustainable development program of Asian coastal tourism. There is a gap between the policy and its implementation in the destination planner (Jackie Ong \& Smith, 2014).

Conventional markets only value certain goods or services in the sea that included fish, other services provided by coastal and marine ecosystems that tend to become degraded. Conservation efforts aimed at protecting coastal ecosystem services, resulting in declining incomes and creating social conflicts. Meanwhile, eco-markets are a market and financial tool, which can, in the right conditions, generated value of a broad portfolio of coastal ecosystem services. While, maintaining the structure and function of ecosystems by addressing the unique problems of coastal zones. Management conservation of coastal areas in the long term aims to maintain the welfare of people living along the coast (Fujita et al., 2013).

Indicators in transition to sustainability in tourism development and planning, identifying characteristics in tourism development. These indicators are currently an important element in the sustainability program. In terms of socio-spatial, there is an indicators for sustainable 


\section{Macrothink}

tourism. It adopted in the planning and management of tourism (Torres-Delgado \& Saarinen, 2014).

Tourism is transforming into a more sustainable development platform. It remains unclear how the concept is embedded at various levels of government policy. It has evolved into a time. The concept of sustainable tourism is the discourse of Australian tourism strategic planning document at national and state level. Lately, there has been a shift in the conceptualization of sustainability with the evolving thoughts of social, natural resources, and economic (Moyle, McLennan, Ruhanen, \& Weiler, 2014).

The public has been faced with a major challenge to refuse or accept the presence of oil companies to drill for oil using a technique known as hydraulic fracturing or fracking. On the other hand, communities are concerned about the negative impacts on such activities justified by coastal communities in their knowledge of sustainable tourism that relies on the social interaction between tourists and local communities and eco-friendly management for the coastal destination of natural resources and economic growth of local people and stakeholders. It has grown on the coast of Newfoundland and Labrador by managing the positive impact that can occur on tourism and other sectors of the economy in West Newfoundland (Edward, 2014).

\section{Methodology}

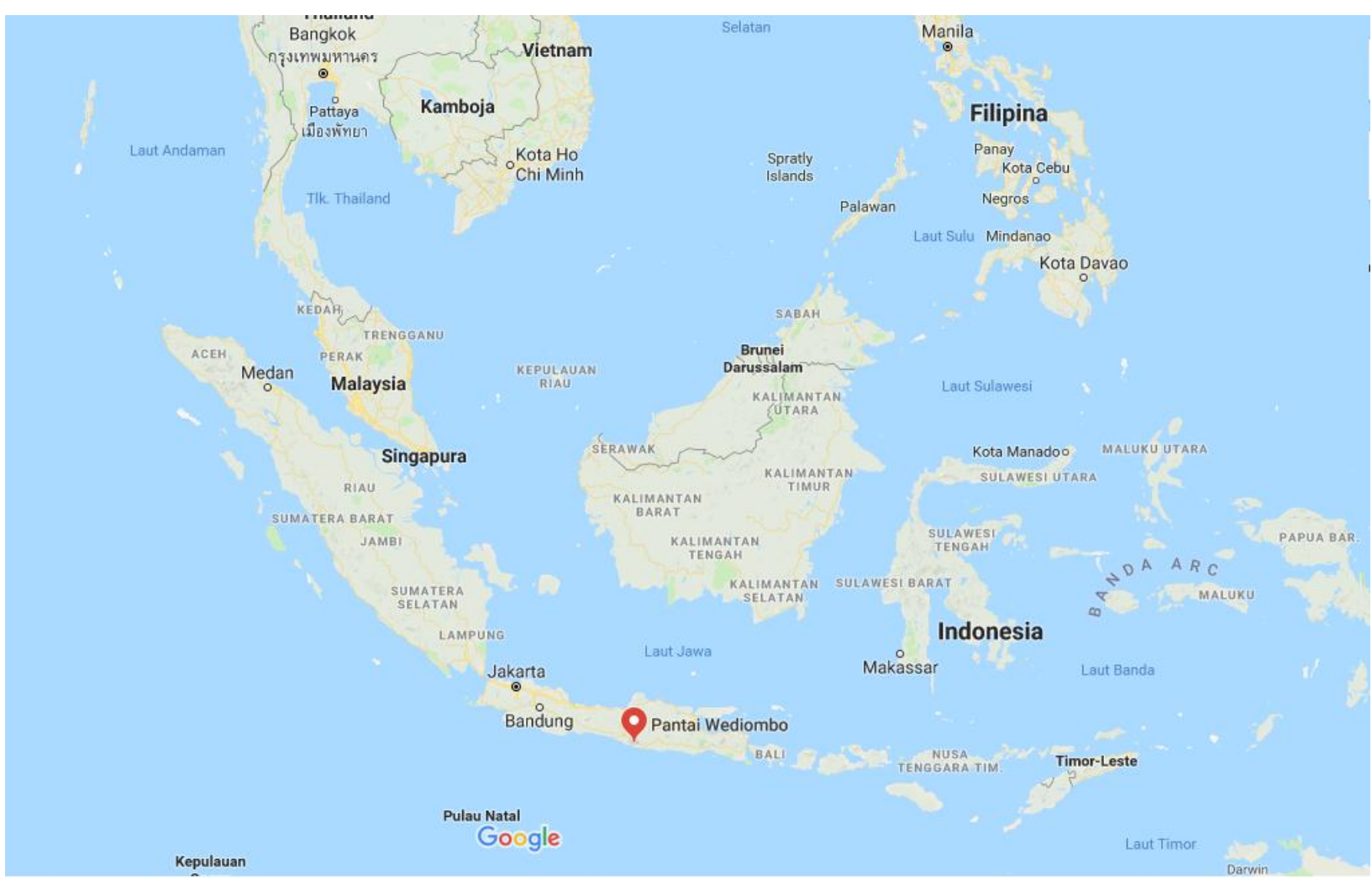

Figure 1. Wediombo coast (Sources:

https://www.google.com/maps/place/Wediombo+Beach)

This research was conducted at Wediombo beach (November 2016 - December 2017), 
Yogyakarta (Cardia \& Jones, 2017; Elo et al., 2014). A 200 questionnaires were distributed randomly and stratified sampling. While, 160 of them responded it. The respondents consisted of tourists and international tourists, local residents, travel agents, tourism departments, and related institutions (van Hoeven, Janssen, Roes, \& Koffijberg, 2015)

Data were collected by purposive stratified sampling and by using triangulation technique (Archibald, 2016; Denzin, 2012; Fielding, 2012): Open observation; Interview structure; and Interviews. In addition, the data is tabulated by content analysis (Grimmer \& Stewart, 2013) based on sustainable coastal tourism: an ongoing exploration of coastal tourism analysis; Parameters of sustainable coastal tourism (Edward, 2014). In addition, posting any parameters of sustainable coastal tourism. The frequency of sustainable coastal tourism is appropriate. Moreover, the frequency of sustainable coastal tourism is calculated. Finally, it got the results analyzed (Tiggemann \& Zaccardo, 2018).

Interview technique using a Focus Group Discussion (FGD). The FGD was the result of a pre-structured semi-structured interview for a tabulation led by a moderator. Moderators are a few questions to get information and opinions from the respondents (Deliens, Clarys, De Bourdeaudhuij, \& Deforche, 2014).

The data collected is tabulated using content analysis (Vaismoradi, Turunen, \& Bondas, 2013). The data processed using Statistical Analysis System (SAS) text software that focuses on content analysis (Hengky \& Kikvidze, 2018; Jahns et al., 2014) Furthermore, this study analyzed each attribute based on Kappa coefficient $=\mathrm{K}$. The coefficients that met the content analysis requirements. In addition, this study discusses the problems that affect each factor of the tabulation result. Some of them are more important. While, the others are less important. Finally, this study analysed sustainable tourism opportunities and strategies in the future to make them reinforce performance (Moyle et al., 2014). Moreover, this study analysed existing and expected performance of Wediombo coast that addressed the gaps.

\section{Results}

This study indicated that Wediombo beach performance (Table 1) is almost towards coastal tourism $(\mathrm{K}=0.58)$. It appears that environmental management still needs to be improved to become a new attraction for tourists. In fact, social interaction among tourists and local residents still need to be improved (0.3085). While, the economic growth of the local community still has not felt its benefits of the natives there. Another social problem is the telecommunication problem of the population and the tourists with the outside world. It is related to the signal strength issue due to the still scarcity of telecommunication networks that support the communication between tourists with their families or business associates during their activities in the coast. These obstacles become a barrier also in the development of tourism in the area. Until now, there is no real action to complete the supporting infrastructure.

Table 1. Existing performance of Wediombo coast

\begin{tabular}{|l|l|l|}
\hline Factors & Value & \% Freq \\
\hline Eco-friendly management for the coastal destination & 35 & 0,3723 \\
\hline
\end{tabular}




\begin{tabular}{|l|l|l|}
\hline Social interaction between tourists and local communities & 29 & 0,3085 \\
\hline Economic growth of local people and stakeholders & 30 & 0,3191 \\
\hline Kappa coefficient $=\mathrm{K}=0.58$ & & \\
\hline
\end{tabular}

Meanwhile, economic growth of Wediombo beach can still be improved (0. 3191), by building telecommunication network infrastructure facilities that will increase the effectiveness of communication among colleagues of tourists which will certainly facilitate communication between them and more importantly is strengthening mouth mouth promotion between colleagues and their families.

Furthermore, improvement on environment-friendly management can increase the motivation of tourists to visit there $(0.3723)$. It can be made by creating a more eco-friendly coastal landscape. So that, the coastal landscape will become more attractive. It becomes an added value of the tourists in their decision to travel there.

Table 2. Expected performance of Wediombo coast

\begin{tabular}{|l|l|l|}
\hline Factors & Value & \% Freq \\
\hline Eco-friendly management for the coastal destination & 34 & 0,3279 \\
\hline Social interaction between tourists and local communities & 38 & 0,3654 \\
\hline Economic growth of local people and stakeholders & 32 & 0,3077 \\
\hline Kappa coefficient $=\mathrm{K}=0.65$ & & \\
\hline
\end{tabular}

Efforts to increase coastal tourism potential and performance at Wediombo beach (Table 2) were carried out by building the quality of communication networks $(0.3654)$ in accordance with the expectations of tourists $(\mathrm{K}=0.65)$. Landscape also improved the performance of the beach (0.3279). Likewise, economic contributes to coastal communities increased (0.3077).

\section{Discussion}

In this study found the main problem in increasing tourism in Wediombo, namely road infrastructure, parking lots, and telecommunications networks. He also hopes the leadership or local government to understand and take advantage of the abundant tourism potential to improve the economy of the community. Increasing the road infrastructure and foreign tourists to visit. (Anugrah, 2017).

In addition to Pindul Cave, Kalibiru, and Glagah Beach, there are another exciting natural tourist destination in Kota Pelajar named Wediombo coast. The tourists certainly should not miss the opportunity to come to the place for fishing activities, surfing, snorkelling, and enjoy the beauty of a natural beach. The tourists that have a hobby of fishing certainly should not miss this one place. In this white sandy beach area there is the Coral Hill is a favorite spot of the anglers to try their fishing ability. In the area there are many marines fishes. It's a Grouper, Mackerel, Cucut fish, even Kakap stone fish that can weigh up to dozens of pounds. Not just fishing, this beach area was used by those who like swimming, surfing, or just playing water. At the beach, there is a hidden pool surrounded by clusters of coral. Pond hidden with a depth of 1.5 meters of this water tended to calm and very clear so much visited by tourists that want to swim. 
Furthermore, this beach is also known as a favourite snorkelling spot of tourists. There are variety of a beach that lives hid in this clear white and watery beach. Coral reefs and cute sea fish that exist there to attract visitors to come there. Think this beach has a very complex biodiversity waters, ranging from fish species to mollusc, crustacean, various types of ornamental fish, shrimp Barong, sea cucumbers, shellfish, sea urchins and seaweed, and also a turtle nesting place. This bay is one of the largest of the nursery ground that is well enough for fish and other aquatic animals. Coral reefs are a form of ocean floor structure of the form of deposits of calcium carbonate produced mainly by coral animals. Corals have no spine properties, and are included in the Coelenterata Phylum or Cnidaria. Coral includes corals from the Order for Scleractinia and the Octocorallia Subclass, as well as the Hydrozoa class. One individual coral or called coral polyps has a size ranging from a very small $1 \mathrm{~mm}$ to a very large that is more than $50 \mathrm{cms}$. However, most coral polyps are small. Polyps are large corals and they lived in solitary corals.

The extent of coral cover in the southern seawaters of Yogyakarta estimated to be about 710 Ha. The coral reefs are scattered along the southern seas of Yogtakarta, with concentrations south of the coast. The coral cover in the coastal waters dominated by the Acroporidae tribe of the Acropora clan. The observation of coral species and coral cover of the beach's waters shows the following results: Dead Coral, Dead Coral with Algae, Acropora Encrusting, Acropora Submassive, Coral Encrusting, Coral Foliose, Submassive Coral, Soft Coral, and Sponges.

Due to tourism activities, they lack of understanding - awareness to preserve the environment of the community and the tourists, there are negative environmental impacts. In this research, they percentage of coral cover on this beach is about a quarter of it in damaged condition (Maulana, Anggoro, \& Yulianto, 2016). Considering coral reefs as common property, coral reef damage is not considered an economic loss so the exploitation of coral reef ecosystem benefits becomes uncontrollable. Coastal management is a challenge to stakeholders to optimize the use of environmental services for community welfare. One component management effort is to monitor the condition of coral reefs at Wediombo Beach. To maintain the coastal ecology, coral reef conservation is needed in the future to maintain the sustainability of coastal tourism on this beach.

Seaweed can be found on this beach that is associated with the existence of coral reef ecosystem. The seaweed can live on sand or dead corals, and grow from the lowest tide to the depths where sunlight is still effective against photosynthesis. Seaweed lives as phytobenthic by sticking or attaching itself to substrate, sand, coral, dead coral fragments, rocks. Furthermore, this one tourist place can be said as one of the beaches are still virgin in Yogyakarta. Its location is far from urban make not many visitors come there. Distance from the city of Yogyakarta to the beach is about 60 miles. Tourists could find a relaxing holiday destination and away from the hustle and bustle of the city, this beach is perfect for their visit. The beach not only offers a stretch of white sand beaches - coral clusters that are still natural. The waves of the beach are also great. So, they can surf on it. While, they enjoyed the dazzling dusk. 
Last year this beach has grown into one of the gathering places for the wave's hunters. Every weekend they come to the beach to enjoy the best waves of the area of Yogyakarta. In contrast to the waves of the Parang-tritis beach where the location is moving, the type of waves of this beach tended to be stable and not changing. While, the beach is shaped like a bay surrounded by coral hills. In addition to having the waves are fun to use for surfing, the beach is also known to have the most spectacular sunset panorama than the surrounding beaches. The beach is facing the West. In November to May, they can watch the sun sink right on the horizon. The scene is very special.

As the name implies Wediombo of "wide sand", this beach has a fairly wide coastline compared with other beaches. To reach the shoreline they have to descend dozens of stairs from the parking lot. The beach is indeed surrounded by hills. The trees that grow around the beach make this beach cool and not arid. Coral reefs that exist in the beach are a geological phenomenon derived from ancient volcano rocks.

Behind the beauty of the beach, stored natural phenomena millions of years old. Geothermal phenomenon that can be found in the Gulf is in the eastern part of the beach is occupied by volcanic rock breakthroughs that are about 40 million years old. Physio graphically, although the constituent rocks of the Sewu Mountain sub-zone are limestone Wonosari Formation, the beach is composed of rhyolite and andesite rocks which are volcanic facials. At the end of the shore is arranged flow of andesitic lava that was boarded with rocks containing volcanic ash issued from volcanic eruptions. There is a volcano lava dome on the western side of this beach and surrounding volcano neck (volcanic neck). The beach is shaped like a semi-circle, estimated the former volcanic crater that sank under the sea water. The existence of the earth's phenomenon can be clearly seen, where in some parts of the coast, especially on the east side there are towering rocks that resemble coral, but have a finer texture than the corals in general. On other hand, they held Ngalagi ritual on the beach once a year. This ceremony is a manifestation of gratitude to the Creator for the abundant harvest and to ask for fortune in the years to come. In addition to a Melarung offerings to sea. The ritual in this there is also activity to catch fish using a net of a Wawar tree. The fish will then be cooked and eaten together at a big event.

Along this coast has a variety of economic potentials ranging from coastal tourism, agriculture, fisheries and livestock, forest, flora and fauna, industry, mining. Most of the agriculture sectors are rain-fed $( \pm 90 \%)$ rainy land depending on the climate cycle, especially rainfall. Irrigate rice fields are relatively narrow. Mining natural resources: limestone, pumice, calcite, zeolite, bentonite, kaolin and quartz sand.

Culinary is a part of sustainable coastal tourism. It can also increase the economic contribution to the local community. Typical mountain food is available there, such as Tiwul, fried grasshoppers, Gatot Gunungkidul, Sego Abang Jirak, and Sayur Lombok Ijo. Tiwul rice of Gunung Kidul is made from cassava flour that is a dried cassava. The rice is a typical food from Gunung Kidul which used to be the staple food of the community in Gunungkidul. Tiwul Rice excellence is on the taste of sweet and savory in arising from the flavor of cassava. in Tiwul Rice can also be added with brown sugar combined with grated coconut. How to 
cultivate very easy, Cassava tree peeled, dried in the sun to dry. Then dried Gaplek mashed up to become flour after. It can be processed into Tiwul.

Fried Grasshopper is processed into foods that have many nutrients. Even wooden locusts have a high protein content that is good for growth. Grasshoppers that have been collected and cleaned it up the dirt. It cooked by way of fried and mixed with special spices. These fried grasshoppers can hold up to one week.

This Gatot is a snack of mountain food made from dried cassava or dried cassava, as well as a Tiwul. Cassava that has been peeled then cleaned then dried for drying purpose to become dried cassava. It soaked during the night. Then steamed for about two hours and in cold right. Furthermore, Sego Abang Jirak is a typical food of Gunungkidul which has high nutrition and healthy food. With the ingredients of brown rice that has high protein content and can be serving as a special vegetable of green chili.

The specialty of this Lombok Ijo Vegetable lies in a savory taste mixed with spicy. The savory taste are caused by the taste of coconut sauce which is quite thick with the added blend of spices such as onions, white, ginger, candlenut, galangal, and some other spices. In addition, Tempe used a complement is taken from a soybean of choice. The Tempe is made in the traditional way, which is wrapped with banana leaves.

\section{Conclusion}

This study found that to fulfil the target of the Head of Yogyakarta Tourism, they get to make the landscaping efforts. It also helped to improve coastal tourism performance. The effort is accompanied by efforts to maintain natural beauty sustainably with coral reef conservation efforts that can enhance snorkeling activities. However, to increase the economic contribution, increasing the potential for culinary tourism can help the economic growth of the coast.

Moreover, the performance of coastal tourism on the coast of Wediombo quite sustainable. It also found a gap between the expectations and actual performance of this beach. The gap can be scaled down by creating new infrastructure and improving communication by building telecommunication networks that are heavily affecting the motives of tourists. In addition, these communication suggestions enhance the ease of communication between tourists with local residents that take part in their travel activities

\section{Implication}

Efforts to safeguard coastal tourism can be done by creating better road infrastructure and building telecommunication networks and preserving the environment with coral reef conservation efforts. To increase the economic contribution to coastal communities, in addition to the potential of coastal tourism, they can also enhance and promote some of the culinary tourism potential that serves their traditional typical food.

\section{Acknowledgement}

The author would like to thank SHINE Institute for helping to distribute the questionnaires to the respondents. In this good opportunity, the author would like to thank the editors and 
anonymous reviewers who have supported in the process of publication of this journal.

\section{References}

Anugrah. (2017). Gunungkidul Regency Requested to Improve Infrastructure Rather than Increase Tourism Levy. Retrieved July 16, 2018, from http://lifestyle.harianterbit.com/lifestyle/2017/11/15/89635/80/38/Pemkab-Gunungkidul-Dimi nta-Perbaiki-Infrastruktur-Ketimbang-Naikkan-Retribusi-Wisata

Ara. (2018). Tourism Visits in 2017 Increased Significantly - Tribune Jogja. Retrieved July 30, 2018, from

http://jogja.tribunnews.com/2018/02/02/kunjungan-wisata-diy-tahun-2017-meningkat-signifi kan

Archibald, M. M. (2016). Investigator Triangulation. Journal of Mixed Methods Research, 10(3), 228-250. https://doi.org/10.1177/1558689815570092

Cardia, G., \& Jones, A. (2017). PM4SD as a Methodological Framework for Sustainable Tourism (pp. 275-292). Springer, Cham. https://doi.org/10.1007/978-3-319-47732-9_19

Deliens, T., Clarys, P., De Bourdeaudhuij, I., \& Deforche, B. (2014). Determinants of eating behaviour in university students: a qualitative study using focus group discussions. $B M C$ Public Health, 14(1), 53. https://doi.org/10.1186/1471-2458-14-53

Denzin, N. K. (2012). Triangulation 2.0. Journal of Mixed Methods Research, 6(2), 80-88. https://doi.org/10.1177/1558689812437186

Dredge, D., \& Jamal, T. (2013). Mobilities on the Gold Coast, Australia: implications for destination governance and sustainable tourism. J. Sustain. Tour., 21(4), 557-579. https://doi.org/10.1080/09669582.2013.776064

Edward, A. (2014). Tourism and "Fracking" in Western Newfoundland: Interests and Anxieties of Coastal Communities and Companies in the Context of Sustainable Tourism. Int. J. Mar. Sci. https://doi.org/10.5376/ijms.2014.04.0002

Elo, S., Kääriäinen, M., Kanste, O., Pölkki, T., Utriainen, K., \& Kyngäs, H. (2014). Qualitative Content Analysis. SAGE Open, 4(1), 215824401452263.

https://doi.org/10.1177/2158244014522633

Fielding, N. G. (2012). Triangulation and Mixed Methods Designs. J. Mixed Methods Res., 6(2), 124-136. https://doi.org/10.1177/1558689812437101

Fujita, R., Lynham, J., Micheli, F., Feinberg, P. G., Bourillón, L., Sáenz-Arroyo, A., \& Markham, A. C. (2013). Ecomarkets for conservation and sustainable development in the coastal zone. Biol. Rev., 88(2), 273-286. https://doi.org/10.1111/j.1469-185X.2012.00251.x

Graci, S. (2013). Collaboration and Partnership Development for Sustainable Tourism. Tour. Geogr., 15(1), 25-42. https://doi.org/10.1080/14616688.2012.675513

Grimmer, J., \& Stewart, B. M. (2013). Text as Data: The Promise and Pitfalls of Automatic 


\section{Macrothink}

Environmental Management and Sustainable Development

ISSN 2164-7682

2018, Vol. 7, No. 4

Content Analysis Methods for Political Texts. Political Analysis, 21(03), 267-297. https://doi.org/10.1093/pan/mps028

Hengky, S. H., \& Kikvidze, Z. (2018). Tourism sustainability in the Bogor Botanical Gardens, Indonesia. Urban Forestry \& Urban Greening, 30, 8-11.

https://doi.org/10.1016/J.UFUG.2018.01.007

Jackie Ong, L. T., \& Smith, R. A. (2014). Perception and reality of managing sustainable coastal tourism in emerging destinations: the case of Sihanoukville, Cambodia. J. Sustain. Tour., 22(2), 256-278. https://doi.org/10.1080/09669582.2013.809091

Jahns, L., Payne, C. R., Whigham, L. D., Johnson, L. K., Scheett, A. J., Hoverson, B. S., \& Kranz, S. (2014). Foods advertised in US weekly supermarket sales circulars over one year: a content analysis. Nutrition Journal, 13(1), 95. https://doi.org/10.1186/1475-2891-13-95

Maulana, H., Anggoro, S., \& Yulianto, B. (2016). Study on the Condition and Value of Coral Reef Ecosystems at Wediombo Beach, Gunung Kidul Regency, Yogyakarta Special Region. Jurnal Ilmu Lingkungan, 14(2), 82. https://doi.org/10.14710/jil.14.2.82-87

Moyle, B. D., McLennan, C. J., Ruhanen, L., \& Weiler, B. (2014). Tracking the concept of sustainability in Australian tourism policy and planning documents. J. Sustain. Tour., 22(7), 1037-1051. https://doi.org/10.1080/09669582.2013.839694

Tiggemann, M., \& Zaccardo, M. (2018). 'Strong is the new skinny': A content analysis of \#fitspiration images on Instagram. Journal of Health Psychology, 23(8), 1003-1011. https://doi.org/10.1177/1359105316639436

Torres-Delgado, A., \& Saarinen, J. (2014). Using indicators to assess sustainable tourism development: a review. Tour. Geogr., 16(1), 31-47.

https://doi.org/10.1080/14616688.2013.867530

Vaismoradi, M., Turunen, H., \& Bondas, T. (2013). Content analysis and thematic analysis: Implications for conducting a qualitative descriptive study. Nursing \& Health Sciences, 15(3), 398-405. https://doi.org/10.1111/nhs. 12048

van Hoeven, L. R., Janssen, M. P., Roes, K. C. B., \& Koffijberg, H. (2015). Aiming for a representative sample: Simulating random versus purposive strategies for hospital selection. BMC Medical Research Methodology, 15(1), 90. https://doi.org/10.1186/s12874-015-0089-8

\section{Copyright Disclaimer}

Copyright for this article is retained by the author(s), with first publication rights granted to the journal.

This is an open-access article distributed under the terms and conditions of the Creative Commons Attribution license (http://creativecommons.org/licenses/by/3.0/). 